\title{
Ergonomic evaluation of conventional and improved methods of Aonla pricking with women workers
}

\author{
Arpana Rai ${ }^{\mathrm{a}, 1}$, Sudesh Gandhi ${ }^{\mathrm{b}}$ and D.K.Sharma ${ }^{\mathrm{c}}$ \\ ${ }^{a}$ Deptt. of Family Resource Management, COHS, CCSHAU, Hisar, Haryana,India \\ ${ }^{b}$ Deptt. of Family Resource Management, COHS, CCSHAU, Hisar,Haryana,India \\ ${ }^{c}$ Deptt. Of AP\&FE, COA\&E,CCSHAU, Hisar, Haryana,India.
}

\begin{abstract}
Conventional and improved methods of aonla pricking were evaluated ergonomically on an experiment conducted for 20 minute with women workers. The working heart rate, energy expenditure rate, total cardiac cost of work and physiological cost of work with conventional tools varied from 93-102 beats. $\min ^{-1}, 6-7.5 \mathrm{~kJ} . \mathrm{min}^{-1}, 285-470$ beats, $14-23$ beats.min $^{-1}$ while with machine varied from $96-105$ beats. $\mathrm{min}^{-1}, 6.5-8 \mathrm{~kJ} \cdot \mathrm{min}^{-1}, 336-540$ beats, $16-27$ beats. $\mathrm{min}^{-1}$ respectively. OWAS score for conventional method was 2 indicating corrective measures in near future while with machine was 1 indicating no corrective measures. Result of Nordic Musculoskeletal Questionnaire revealed that subjects complaint of pain in back, neck, right shoulder and right hand due to unnatural body posture and repetitive movement with hand tool. Moreover pricking was carried out in improper lighting conditions (200-300 lux) resulting into finger injuries from sharp edges of hand tool, whereas with machine no such problems were observed. Output with machine increased thrice than hand pricking in a given time. Machine was found useful in terms of saving time, increased productivity, enhanced safety and comfort as involved improved posture, was easy to handle and operate, thus increasing efficiency of the worker leading to better quality of life.
\end{abstract}

Keywords: Aonla preserve, hand tool, aonla machine

\section{Introduction}

Aonla popularly known as Indian Gooseberry (Emblica officinalis Gaertn) is an important fruit crop indigenous to Indian sub-continent. India ranks $1^{\text {st }}$ in area and production of aonla and aonla are second highest among all the cultivated fruits in India. Owing to its high productivity/unit area (15-20tons/ha), nutritive and therapeutic value, aonla is becoming more and more commercially important with every passing year. Status of post harvest technology of aonla in India shows that aonla has a growing popularity for alternate medicines, health foods and herbal products. Because of its highly astringent nature, the consumers do not relish the fruit in fresh form. Hence, it is necessary to process the fruit and develop novel innovative products of high value. The need of hour is to mechanize processing operations to produce quality products of aonla for domestic as well as global market [3].

The aonla preserve (murabba), a value added aonla product is one of the specialties of the Indian fruitpreservation industry with hundreds of tons sold every year. The preserve making is amongst the oldest cottage industries in India engaging a considerable no of women in pricking operation. Women are vital and productive workers in these industries. Traditionally in Small and medium Scale Enterprises (SMEs) preserve is prepared by pricking aonla fruits with wooden or stainless steel needles followed by keeping them in sugar syrup. The pricking task is highly repetitive, tiresome, time consuming and is done manually with naked hands and poorly designed tool having sharp pricking edges. Many times, workers get finger injuries during this operation resulting into itching and infections which has great impact on quality of work, aonla preserve and health of workers.

\footnotetext{
${ }^{1}$ Corresponding author

Email:arpanahau@gmail.com
} 
The work is often performed in undesirable posture; therefore pricking workers have a risk for pain due to musculoskeletal problems. Additionally the work is highly vision demanding since pricks are to be made carefully in each aonla fruit. In such working circumstances workers are prone to develop various health hazards.

To overcome all these drawbacks associated with conventional tool, a hand operated aonla pricking machine has been developed by the All India coordinated Research Project on Post Harvest Technology, Hisar in College of Agricultural Engineering and Technology [1]. To be on the safer part every machine whether large or small must undergo an ergonomic assessment to avoid man -machine conflict in the work place which in turn will enhance work efficiency and productivity. There are now an increasing number of ergonomics interventions in agricultural and allied operations where performance on productivity, health and safety has been improved. The supreme purpose of combining ergonomics with food processing units is to reduce occupational workload on women working in these industries by devising the appropriate tool, equipment and advanced technologies for them. So far our knowledge is concerned no such research has been carried out in our country pertaining to aonla pricking operation, so this study will prove to be boon for preserve making cottage industry and workers involved in these industries. However similar researches on other agricultural tools and implements have been conducted.

Ergonomic evaluation of hand operated paddy winnower with 12 women subjects in standing posture revealed that mean heart rate (HR), energy expenditure rate (EER) during operation was 112 beats. $\mathrm{min}^{-1}$ and $10.7 \mathrm{KJ} . \mathrm{min}^{-1}$ respectively and output was $242 \mathrm{~kg}$ grain /hr. [11]. Paddy threshing activity by farm women using two methods, manual beating of paddy on wooden platform and by using manually operated paddy thresher revealed that mean HR, EER for manual beating of paddy was 154.5 beats. min $^{-1}$, 17.64 KJ.min ${ }^{-1}$ whereas it was 122.5 bbeats. $\mathrm{min}^{-1}$ and $12.80 \mathrm{KJ} \cdot \mathrm{min}^{-1}$ respectively with manually operated paddy thresher. The Total Cardiac Cost of Work (TCCW) and Physiological Cost of Work (PCW) reduced by 60.28 percent with the use of paddy thresher [7]. Similarly the present research assesses conventional and improved methods of aonla pricking on ergonomic parameters to have more output and improving health and safety of the worker.

\section{Material and methods}

The present study aimed at evaluating the performance of machine over conventional methods in terms of time spent, energy expenditure, physiological cost of work (PCW), postural variations and body part discomfort experienced and the output. The ergonomic evaluation of pricking task was conducted with 6 women workers of aonla processing small scale enterprises of Hisar Distt., Haryana using 2 methods viz. manual pricking with conventional tool and by manually operated aonla pricking machine for 20 min each. The conventional tool was operated by women workers in sitting posture and machine in standing posture. Physical (age, weight, height, BMI), environmental parameter (light) and working posture (sitting and standing) taken as independent variable were analyzed to study their impact on safety and

Table 1

Salient Specification of Conventional Tool and Machine

\begin{tabular}{clll}
\hline S.No. & Specification & Conventional tool & Machine \\
\hline 1 & Weight of tool/machine $(\mathrm{kg})$ & .3 & 8.135 \\
\hline 2 & Length of tool/machine & $18.7 \mathrm{~cm}$ & - \\
\hline 3 & Material of tool/machine & $\begin{array}{l}\text { Wooden handle with } \\
\text { stainless steel needles }\end{array}$ & $\begin{array}{l}\text { Body made up of mild steel, Teflon square blocks } \\
\text { with stainless steel needles , plastic handle }\end{array}$ \\
\hline 4 & No of needles & 25 & 50 on each Teflon plate \\
\hline 5 & $\begin{array}{l}\text { Force required to operate } \\
\text { tool/machine }(\mathrm{kg})\end{array}$ & 3 & 1.4 \\
\hline 6 & Output $(\mathrm{kg} / \mathrm{hr})$ & $5-6$ & $15-20$ \\
\hline
\end{tabular}




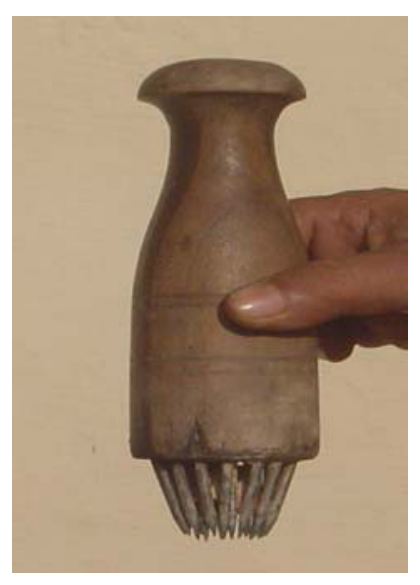

Conventional tool

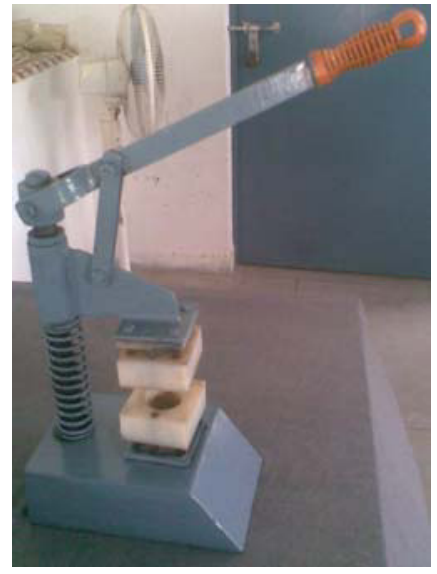

Machine comfort of workers, productivity (output) of machine, physiological (heart rate, energy expenditure, physiological cost of work, Total cardiac cost of work), biomechanical (grip strength) and psychophysical (body part discomfort experienced) parameters taken as dependent variable. The salient features of conventional tool and improved machine has been presented in Table 1.

\subsection{Selection of subjects}

All the selected subjects were in the age group 20-35 yrs because people usually attain their highest strength level between this age group. Body height, weight and Body mass index of each subject was measured. All the subjects were right handed, physically fit and were not suffering from any physical abnormalities to perform the selected activity.

\subsection{Calibration of subjects}

The subjects were allowed to take sufficient rest before starting the activity to determine the resting heart rate and grip strength was measured for both the hands at rest and 15 min prior of conducting the experiment.

\subsection{Assessment of ergonomic parameters}

\subsubsection{Measurement of Heart Rate}

A polar heart rate monitor was used for recording heart rate of women workers during course of study. The monitor consisted of chest strep and wrist watch type receiver. Data for resting, working and recovery heart rate were taken for the period of 10 $\mathrm{min}, 20 \mathrm{~min}$, and $10 \mathrm{~min}$ respectively. The heart rate data from $6^{\text {th }}$ min onwards of work of each worker was considered for calculating the heart rate as it is considered that workers heart rate get stable after 3-5 $\min [8]$.

\subsubsection{Energy Expenditure}

Energy expenditure during work was also calculated by Average heart rate (AHR) by using the regression equation [12].

Energy Expenditure $(\mathrm{KJ} / \mathrm{min})=0.159 \times$ AHR $(\mathrm{bpm})$ $-8.72$

\subsubsection{Classification of Workload}

Workload of the activity was categorized as per the following classification of workload [12].

Table2

Classification of Workload

\begin{tabular}{ccc}
\hline Variable & $\begin{array}{c}\text { Energy expendi- } \\
\text { ture (kj.min }\end{array}$ & $\begin{array}{c}\text { Heart rate } \\
\text { (beats.min }\end{array}$ \\
\hline Very light & Up to 5.0 & UP to 90 \\
\hline Light & $5.1-7.5$ & $91-105$ \\
\hline Moderate & $7.6-10.0$ & $106-120$ \\
\hline Heavy & $10.0-12.5$ & $121-135$ \\
\hline Very heavy & $12.6-15.0$ & $136-150$ \\
\hline Extremely & $<15.0$ & Above 151 \\
heavy & & \\
\hline
\end{tabular}

\subsubsection{Physiological Cost of Work}


Physiological workload refers to "physical or muscular effort required on the part of worker to accomplish a task or activity". The period during which work continues is known as work period and period during which the physiological functions returns to normal level is known as recovery period. Hence to evaluate total physiological expenditure, physiological reactions both during the work and during the recovery period are considered. From HR value Total Cardiac Cost of Work (TCCW) and physiological cost of work (PCW) were calculated.

$\mathrm{TCCW}=$ Cardiac Cost of Work $(\mathrm{CCW})+$ Cardiac Cost of Recovery (CCR)

$\mathrm{CCW}=($ Avg. Working HR- Avg. Resting HR) $\mathrm{x}$ Duration of Activity

$\mathrm{CCR}=($ Avg. Recovery HR - Avg. resting HR $) \mathrm{x}$ Duration of activity

$\mathrm{PCW}=\mathrm{TCCW} /$ Total time of activity

\subsubsection{OWAS method}

A video during pricking action, showing different movements of worker was recorded. After recording the video, it was cropped after every 10 seconds to get snapshots for analysis of posture of the workers. The snapshots were analyzed to fill the score of OWAS sheet. The OWAS method uses the concept of number to represent posture with an associated coding system. The jobs with the involvement of high risk were numbered higher and those with the less risk involvement were numbered low. Immediate corrective actions and necessary changes were recommended for activities numbered higher to avoid any risk [5].

\subsubsection{Standard Nordic musculoskeletal questionnaire}

A detailed study based on Modified Nordic Musculoskeletal questionnaire information (current pain in immediate past 7 days and previous pain in last 12 month) was performed on women workers. The questionnaire consists of series of objective type questions with multiple type responses. The face to face interview was thought to be more reliable in obtaining accurate information [6].

\subsubsection{Light}

Adequacy of lightning is very important for comfortable performance of work without putting harmful strain on eyes as pricking with conventional tool is highly vision demanding. Light intensity in selected work areas were measured using lux meter.

\subsubsection{Hand tool injuries}

Simple observational studies were carried out to evaluate the hand tool injuries due to conventional tool.

\subsubsection{Biomechanical stress}

Biomechanical stress is the stress in the muscles in the body while working. It is measured using grip fatigue. Grip diameter was used to measure the stress of grip strength. Grip strength was measured at rest i.e. before the start of activity ( $\mathrm{Sr}$ ) separately for right and left hand and then immediately after the completion of the activity (Sw). Grip fatigue is calculated as given below [9]

Grip Fatigue $(\%)=\mathrm{Sr}-\mathrm{Sw} \times 100 / \mathrm{Sr}$

\subsubsection{Body part discomfort}

Body part discomfort during pricking activity was observed using Corlett and Bishop method in which several numbered body diagrams were produced. After every half an hour interval, worker were asked to indicate on the diagram the body area(s) which were most painful. Having noted these, the next most painful areas were asked far and so on, till no further areas were referred [2].

\section{Results and discussions}

\subsection{Physical characteristics}

The physical characteristics of the respondents are presented in Table 2. It depicts that mean age of women workers was 27 years having height $154 \mathrm{~cm}$ and weight $50 \mathrm{~kg}$ respectively. Body Mass Index was calculated from weight to height ratio and was observed as 21 .

Table3

Physical characteristics of respondents

\begin{tabular}{lll}
\hline Parameters & Range & Mean \\
\hline Age $($ Years $)$ & $20-35$ & 27 \\
\hline Weight $(\mathrm{Kg})$ & $45-55$ & 50 \\
\hline Height $(\mathrm{cm})$ & $148-160$ & 154 \\
\hline BMI & $20.5-21.5$ & 21 \\
\hline
\end{tabular}

The results of the study revealed that there was slight difference while working with both methods in terms of working HR, EER and PCW.

\subsection{Heart Rate}


The average working HR of the worker when pricking was done with conventional tool ranged between $93-102$ beats. min $^{-1}$ with the mean HR value of 97 beats. $\mathrm{min}^{-1}$. The corresponding HR value with machine ranged between $96-105$ beats. min $^{-1}$ with mean value of 100 beats. $\mathrm{min}^{-1}$. The heart rate recovered to its peak rest stage after $5 \mathrm{~min}$ in case of conventional tool whereas it was 6 min when machine was used. This shows that rest pause of $6 \mathrm{~min}$ could be given to the worker in both cases before restarting the job. However more rest may be needed to subside the muscular fatigue developed during the pricking activity.

\subsection{Energy Expenditure}

Energy expenditure during pricking with conventional tool varied between $6-7.5 \mathrm{~kJ} \cdot \mathrm{min}^{-1}$ with the mean value of $6.75 \mathrm{~kJ} . \mathrm{min}^{-1}$ whereas with machine it varied between $6.5-8 \mathrm{~kJ} \cdot \mathrm{min}^{-1}$ with the mean value of $7.25 \mathrm{~kJ} \cdot \mathrm{min}^{-1}$.

\subsection{Classification of workload}

As per classification of work given by Varghese, the pricking work with both conventional tool and machine could be categorized as 'light' based on heart rate and energy expenditure data; however these values are slightly higher with machine. The acceptable workload for Indian workers would be at the heart rate of about 110 beats. $\mathrm{min}^{-1}$. The heart rate during operation with both tools was within the acceptable limit and heart rate did not restrict the use both conventional tool and machine [10].

\subsection{Total cardiac cost of work and physiological cost of work}

The TCCW varied between $285-470$ beats with conventional tool with mean value of 377 beats and 336-540 with improved machine with mean value of 438 beats. The corresponding PCW with conventional tool varied between $14-23$ beats. min $^{-1}$ with mean value of 18 beats. $\min ^{-1}$ and with improved machine varied between $16-27$ beats. min $^{-1}$ with mean value of 21 beats. $\mathrm{min}^{-1}$.

\subsection{Posture and OWAS results}

With conventional tool sitting posture was adopted because the workers insisted that they will be comfortable in sitting posture and it is the only posture they adopted while pricking, however for smooth working with machine standing posture was assumed to be comfortable. OWAS score for conventional methods was 2 because the work was carried out in sitting posture with both leg folded and back and shoulder bent. This score implies that working in this posture requires corrective measures in near future. However, no such problems were observed with improved method as machine pricking was done in standing posture with machine placed at ergonomically designed work station i.e. 3 inches below the elbow height of workers, at height of $88 \mathrm{~cm}$ from ground thereby involving very slight bending of back and neck. OWAS score with improved tool was 1 which indicates no corrective measure.

\subsection{Light and hand tool injuries}

Light intensity must match the activity being performed. Since pricking with conventional tool is vision demanding as pricks are to be made carefully on individual fruit and this categorizes it as moderately precise work with lighting requirement of 300-500 lux [4]. But the lighting in the working area was only 200-300 lux, demanding high concentration on part of workers while pricking otherwise resulting into figure injuries from sharp edges of conventional tool which took a recovery time of 7 days and eye aches. While no such problem was observed with machine as light of 200-300 lux was sufficient for working with machine because in machine picks were made automatically by the stainless steel needles mounted on oppositely placed Teflon blocks controlled through handle of machine.

\subsection{Grip fatigue}

The grip fatigue of left hand and right hand (working hand) while working with conventional tool was 1.5 percent and 2.8 percent respectively and on machine was 1.24 percent and 3 percent respectively. However perception of the workers was that machine is more convenient to handle and operate as the plastic handle is not slippery and does not built up stickiness, while wooden handle of conventional tool was slippery.

\subsection{Body part discomfort and Nordic results}


Rating of body part discomfort as reported by the subjects indicated that while working with conventional tool the most frequent body part with discomfort were neck, backbone (unnatural body bent at cervical and lumbar region), right shoulder, right hand, right wrist, and figures and palm of both hands. Almost all subject complaint of maximum discomfort in right wrist due to its high repetitive movement, figures and palm of both hands and this feeling usually lasts for 2-3 days. While working on machine subject complaint of very mild pain in right hand and that only during main harvesting season when they spend nearly 6-7 hr per day in pricking otherwise 20 min work does not cause discomfort and if any it usually subsides after small rest.

\subsection{Output parameter}

Machine was found to be advantageous over hand pricking as with machine workers were able to prick thrice the amount of aonla as that with the conventional tool in a given time. The output with conventional tool varied between $2-3 \mathrm{~kg}$ in 20 minute while with machine the amount pricked in 20 minute was 6-7 kg.

Table 4

ERGONOMIC PARAMETERS WITH CONVENTIONAL TOOL AND IMPROVED METHOD

\begin{tabular}{|c|c|c|}
\hline $\begin{array}{l}\text { Ergonomic Parame } \\
\text { ters }\end{array}$ & $\begin{array}{l}\text { Conventional } \\
\text { Method }\end{array}$ & $\begin{array}{l}\text { Improved } \\
\text { me- } \\
\text { thod(machine) }\end{array}$ \\
\hline Heart rate(bpm) & 97 & 100 \\
\hline $\begin{array}{l}\text { Energy expenditure } \\
(\mathrm{KJ} / \mathrm{min})\end{array}$ & 6.75 & 7.25 \\
\hline workload & light & $\begin{array}{l}\text { Slightly mod- } \\
\text { erate }\end{array}$ \\
\hline $\begin{array}{l}\text { Total Cardiac Cost of } \\
\text { Work (beats) }\end{array}$ & 377 & 438 \\
\hline $\begin{array}{l}\text { Physiological cost of } \\
\text { work(bpm) }\end{array}$ & 18 & 21 \\
\hline OWAS Score & 2 & 1 \\
\hline Light(200-300 lux) & Not sufficient & sufficient \\
\hline Hand tool Injuries & Figure injuries & - \\
\hline $\begin{array}{l}\text { Grip Fatigue (\%) } \\
\text { (left hand, right hand) }\end{array}$ & $1.5,2.8$ & $1.2,3$ \\
\hline $\begin{array}{l}\text { Body Part discomfort and } \\
\text { Nordic Musculoskeletal } \\
\text { Questionnaire }\end{array}$ & $\begin{array}{ll}\text { neck, } & \text { back- } \\
\text { bone, right } & \text { upper } \\
\text { extremity } & \\
\end{array}$ & right hand \\
\hline Output(kg) & $2-3$ & $6-7$ \\
\hline
\end{tabular}

\section{Conclusion:}

Although working with hand pricking tools indicates light workload i.e. low physiological stress on the subjects yet it has low efficiency in terms of output of the worker. The working conditions were not ergonomically sound as the work was carried out in improper lighting, increasing the incidences of injuries viz. cuts and wounds in the fingers, eye aches and incorrect posture involving unnatural body bent thereby exposing workers to musculoskeletal problems and posing a hazard to biomechanical and psycho physiological safety and comfort of workers. However no relation was found between angles of body bent and heart rate. Aonla pricking machine was found useful in terms of saving time, increased work capacity \& productivity with light workload and consequently enhanced safety \& comfort of the worker. Further machine was compatible, easy to handle and operate and involved improved posture during work thus increasing efficiency of the worker leading to better quality of life. Hence, it can be concluded that intensive, repetitive work with conventional tool results in costly health problems (direct cost), and lost productivity (indirect cost) while machine was found to be ergonomically sound, women friendly and drudgery reducing. Hence with the use of machine women can achieve maximum work efficiency with minimum danger to health.

\section{References:}

[1] Annual Report of AICRP on PHT, 2008. CCS Haryana Agriculture University, Hisar

[2] Corlett NE; Bishop RP. 1976. A technique for assessing postural discomfort. Ergonomics. 19, 175182

[3] Goyal RK; Patil RT; Kingsly ARD; Himanshu W; Pradeep K. 2008. Status of post harvest technology of aonla in India - A review. Am. J. Food Technol, 3: $13-23$.

[4] E. Grandjaen, Ergonomics of the Home. 1978.Taylor and Francis Ltd. London

[5] Karhu O, Kansi P, Kuorinka I. Correcting work posture in Industry: a practical method for analysis. Applied Ergonomics. 8 (1977), 199-201

[6] Kuorinka I., Jansson B., and Killom A. 1987. Standard Nordic Questionnaires for the analysis of musculoskeletal symptoms. Applied Ergonomics, 18(3): 233-237.

[7] Kwatra S; Vinay D; Sharma S. 2010. A comparative study on the manual beating of paddy and manually operated paddy thresher on farm women. J Hum Ecol, 32(3): 183-187.

[8] Le Blanc JA. 1957. Use of heart rate as an index of workload. J. Applied Physiology, 38, 275-280.

[9] Oberoi K; Singh S.2007. Methodologies for assessment of ergonomic cost of work. In: Ergonomic In- 
tervention for Health and Productivity. Himanshu publication, Udaipur

[10] Saha P N;Banerjee S R;Banerjee P K;Narayana G.1979 An acceptable woerkload for Indian workers. Ergonomics, 22(9), 1059-1071

[11] Singh S.P; Gite L.P. 2007.Ergonomic evaluation of hand operated paddy winnower by women worker. $\mathrm{J}$ of Agricultural Engineering, 44(4):67-71

[12] Varghese M. A; Saha P.N; Atreya N. 1994. A rapid appraisal of occupational workload from a modified scale of perceived exertion. Ergonomics, 37, 485491 